\title{
MORPHOLOGICAL AND IMMUNOHISTOCHEMICAL EXAMINATION OF TUMOR CELLS IN MAREK'S DISEASE
}

\author{
PEJOVIĆ $N^{*}$, VELHNER MAJA**, POLAČEK V**, ALEKSIĆ-KOVAČEVIĆ SANJA***, \\ MARINKOVIĆ $D^{* * *}$ and KNEŽEVIĆ MILIJANA*** \\ * Biotechnical Institute, Podgorica, Republic of Montenegro; \\ ** Scientific Veterinary Institute "Novi Sad", Novi Sad; \\ $\star \star \star$ Faculty of Veterinary Medicine, Belgrade \\ (Received 1. June, 2006)
}

In this paper are described the macroscopic, microscopic and immunophenotypic characteristics of tumors in Marek's disease (MD). Liver, kidneys, lungs, heart, proventriclus, ovary and nerves of sciatic plexus collected from 20 chickens aged 8 to 24 weeks were examined.

Lymphoproliferative enlargement in various organs of focal and diffuse character was found. The affected organs were enlarged, compact and very brittle, irregular in shape, grayish-red or grayishwhite and of fatty consistency. Most often characteristic changes were in the spleen, liver, proventriculus and ovary that usually had a compact or ribbed, fatty cauliflower like formation, different in size. On histological examination proliferation of small and medium size lymphocytes, lymphoblast cells, Marek's disease cells and activated reticulum cells were found. Tumor proliferates predominantly consisted of lymphoblasts and had all the characteristics of a lymphoma. Immunohistochemical analysis revealed that lymphoma cells in MD are of $C D 3$ + phenotype. In liver proliferates numerous CD79+ cells were found perivasculary, which is an interesting finding demanding further research.

Key words: Marek's disease, pathohistology, immunohistochemistry, CD3, CD79

\section{INTRODUCTION}

One of the most ubiquitous viruses in poultry is the Marek's disease virus (MDV). The MDV causes a lymphoproliferative disease that appears in a visceral and neurological form. Skin tumors and ocular lesions have been reported as well (Ficken et al., 1991; Witter and Schat 2003).

The virus belongs to the subfamily Alphaherpesvirinae of the family Herpesviridae (Witter and Schat, 2003). MDV genome is linear and double stranded. There are about 70 to 80 genes that are responsible for biological functioning of the virus. Products of genes C, B and pp38 are important in 
inducing the immunologic response. Usually, chickens are infected by inhalation of fully infectious viral particles. MDV therefore appears in the lungs shortly after inhalation. Next, the virus resides in the lymph organs (bursa, thymus and spleen) where an acute cytolytic infection, also called productive infection, is established. The enveloped MDV is produced in the feather follicle epithelium during the productive infection. In productive-restrictive infections antigens are produced while the virus is nonenveloped-noninfectious. Latent infection is characterized by the presence of viral genome in the cells accompanied with low, if any, antigen expression. The virus antigens and viral particles can be produced in this stage of infection upon in vitro cultivation. Transformed cells do express some viral antigens such as pp38. MD tumor associated surface antigen (MATSA) is present in MD lymphomas also and could be used for differential diagnosis of MD (Calnek, 1989).

There are three serotypes of MDV. Serotype 1 consists of pathogenic strains and a low pathogenic vaccine strain CVI988 (Rispens strain). In the serotype 2 group are naturally attenuated vaccine strains isolated from chickens, whilst serotype 3 consists of MDV isolated from turkeys.

Because chickens are exposed to the infection very early they must be protected by vaccination as soon as possible, therefore vaccination in hatcheries is practiced worldwide (Witter and Schat, 2003; Sharma et al., 2002). A new pathotype of MDV that emerged on the field caused to switch the vaccination strategy to vaccines that present a mixture of several serotypes (Witter and Lee, 1984; Baigent et al., 2006). In spite of well-developed protocols for protection against MDV, some countries reported outbreaks caused by new pathogenic virus strains (Witter, 1997).

Pathohistologic examination of proliferate lesions is of paramount importance in diagnosing MD. Lymphomatous lesions consist of small and medium size lymphocytes and blast cells. The cells are pleomorphic and vary in size (Payne, 1976). The target cells for malignant transformations are mostly of CD4+CD8- phenotype (Schat et al., 1991). Therefore, besides the morphological appearance, and the pathohistologic examination, immunohistochemical staining can help in differentiating MDV from lymphoid leucosis (LL) as well as from other neoplastic diseases.

During this work, organs from the chickens from different farms, suspected to have died from MDV, were examined morphologically, by pathohistological and immunohistochemical procedures. We are reporting also, that human CD3 antibodies can be successfully used as cell markers on paraffin wax processed tissue from MDV infected chickens.

\section{MATERIAL AND METHODS}

\section{Experimental chickens}

Chickens from various farms that had most likely died from MDV infection were delivered to the Veterinary Pathology Institute for diagnosis. Twenty birds between 8 and 24 weeks of age were included in the study. All these birds were raised under conditions of proper farm management and the disease was 
suspected upon routine veterinary inspection. The overall percent of mortality on these farms was not significant, thus pointing that these farms did not experience significant MDV problems. The following organs were examined: liver, spleen, kidneys, proventriculus, lungs, heart, ovary and sciatic nerve.

\section{Pathohistology and immunohistochemistry procedure}

The organs were fixed in $10 \%$ neutral formalin, paraffin embedded, cut in $5 \mu \mathrm{m}$ sections and stained with Hematoxiline-eosine and Giemsa.

The streptavidin-biotin (LSAB) commercial detection kit (Chemmate K 5003) was used for the staining procedure in order to detect CD3 (T- lymphocytes) and CD79 (B-lymphocytes). The following primary and secondary antibodies were used in this work:

- mouse-anti-human CD79 (DAKO M7051), at dilution of 1:50, for $60 \mathrm{~min}$, in a humid chamber at $18^{\circ} \mathrm{C}$;

- mouse-anti-human CD3 (DAKO A 0452) at dilution of 1:50, for 60 min., in humid chamber at $18^{\circ} \mathrm{C}$;

- control mouse monoclonal antibodies (Kontr. T1-Inst. Vet. Path., Giessen);

- control monoclonal rabbit (Kontr. T2-Inst. Vet.Path., Giessen). K5993).

The detection kit was ${ }^{\mathrm{tm}}$ Detection Kit Peroxidase/aec, Rabbit/mouse (DAKO

The paraffin embedded sections were heated in a microwave oven at $560 \mathrm{~W}$ for 21 minutes in citrate buffer $\mathrm{pH}=6$ before antibodies staining. All rinsing procedures and sera dilutions were done in PBS $\mathrm{pH}=7.2-7.4$. Before incubation with primary antibodies the sections were incubated with $10 \%$ goat sera in PBS for 20 minutes. Afterwards the sections were further incubated with primary antibodies and visualized by applying aminoethilcarbasole AEC for 10 to 12 minutes or by applying DAB for 3 to 5 minutes. Counter staining with hematoxiline and eosine was done for 10 seconds. We used water medium glycergel (DAKO C563) on stained sections. Following organs were stained with CD3 antibodies: liver, spleen, kidney, proventriculus, lungs, heart, ovary and schiatic nervs. Liver sections were also stained for CD79.

\section{RESULTS}

\section{Morphological examination}

Upon the pathology examination the following observations were made:

The affected livers were enlarged with rounded edges, while multiple tumors were gray or yellow (Figure 1a). The spleen was enlarged, dark red and of fatty consistency. In some cases gray-yellow nodules of different shapes were seen. The kidneys were also enlarged, irregular in shape and fatty consistency. Round gray-yellow nodules were present in some cases. Pathology examination of plexus sciatic at the right side showed enlarged nerves ( 2 to 3 times thicker) gray or yellow color (one case). The affected ovaries were prominent and had cauliflower-fatty appearance. In some cases the tumors had a light red color and in other cases they were a few millimeters enlarged of a white or gray color. The 
proventriculus was in some cases diffusely enlarged or the nodules were dispersed over the organ. The proventriculi affected with tumors were white and gray, and they displayed a fatty appearance. Small dotted bleeding could be seen, as well as superficial or deep erosions. In the lungs, tumors could be seen on multiple sites. They had a fatty consistency and could be clearly distinguished from the red parenchyma of the lungs. In one case, the myocardium was enlarged and interwoven with fatty spots and lines.

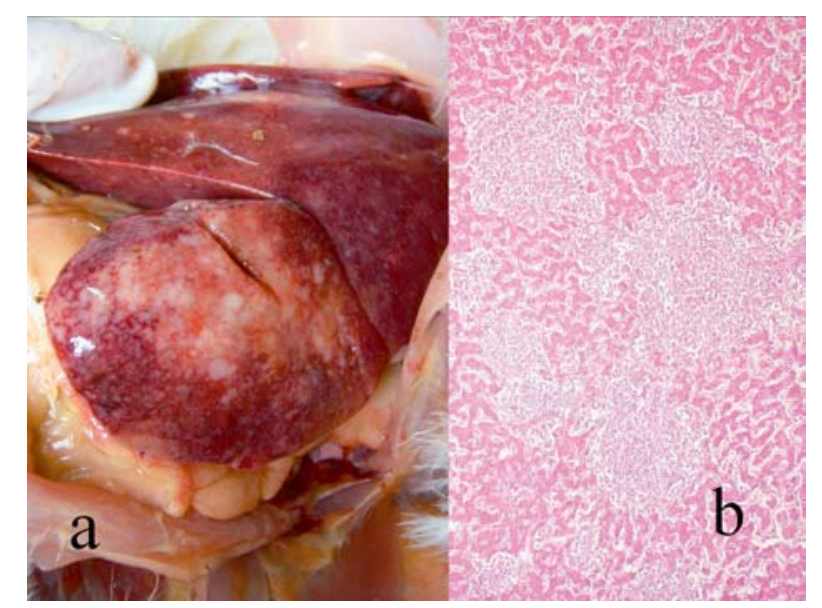

Figure 1 a, b Liver, morphological changes in Marek's disease

\section{Pathohistological finding and immunohistochemical staining}

\section{Liver}

Microscope examinations of affected livers revealed many lymphomatous cells situated perivasculary. Tumor proliferates were diffused sometimes so vastly that only parts of the Remarck isthmus could be seen. The tumor proliferates consisted of pleomorphic lymphocytes (Figure 1b). Besides the large rounded cells enriched with cytoplasm, cells with dense chromatin were also present. A smaller number of cells appeared as small lymphocytes with hyperchromatine nucleus and narrow cytoplasm. Most of these cells were CD3 stained in a form of membrane precipitate, red or brown color (depending on hromogen) (Figure 2a). CD79 positive cells were clearly seen in tumors, mostly perivasculary although the staining was weak comparing to CD3 (Figure 2b).

Spleen

In the spleen sections a large number of tumor cells that disturb the normal texture of the organ could be seen. Sometimes the tumor proliferates containing small, medium and large lymphocytes, were situated perivascularly as small or larger foci. Most of the cells were stained positive on CD3. 
Acta Veterinaria (Beograd), Vol. 57. No. 1, 27-35, 2007

Pejović $\mathrm{N}$ et al.: Morphological and immunohistochemical

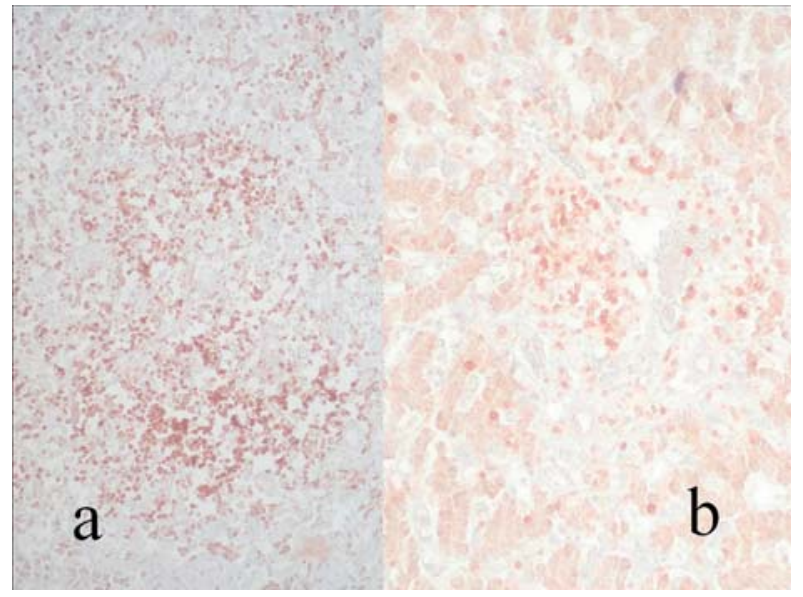

Figure 2 a, b. Liver, expression of CD 3 and CD 79 in Marek's disease

Kidney

The polymorphic tumor proliferates were situated periglomerularly or peritubulary. The intensity of proliferation varied from focal to intensive accumulation of tumor cells, hence the kidney structure elements were rare. The immunophenotype of transformed cells was CD3 positive showing that this cell line was affected and transformed (Figure $3 \mathrm{a}, \mathrm{b}$ ). Small number of scattered CD79 positive cells were found in the kidneys.

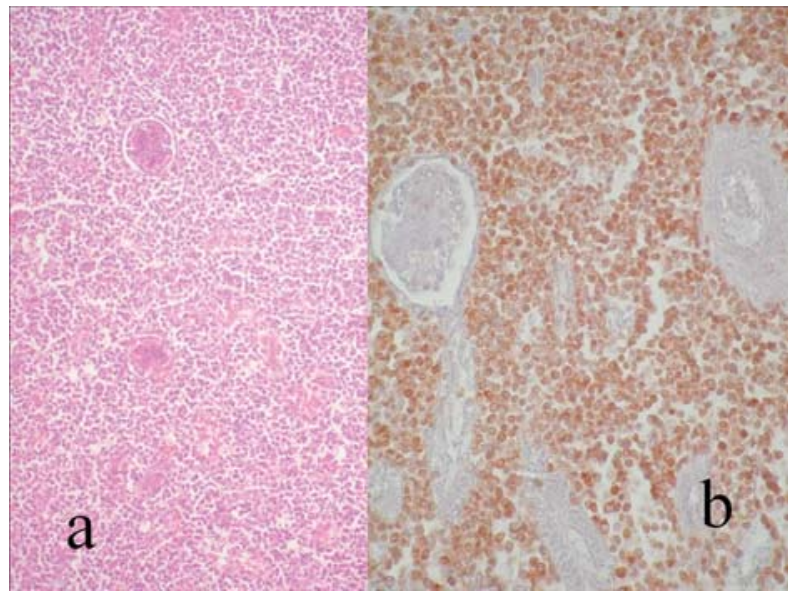

Figure 3 a, b. Kidney, pathohistological finding and expression of CD 3 in Marek's disease 


\section{Proventriculus}

There were diffuse tumor proliferates in all the layers of the proventriculus. Besides diffused proliferates the clearly restricted foci of tumor cells that look like lymph follicles were seen. Positive membrane CD3 staining was detected in single intraepithelial and diffused lymphocytes of the mucosa lamina propria. Tumor cells in groups similar to lymph follicles also tested CD3 positive. Few CD79 positive cells were also found in tumor lesions.

\section{Lungs}

Tumor proliferates were localized peribronchially and perivasculary. In most cases tumor proliferates were so severe that the normal texture of the lungs could hardly be seen. The tumor cells were stained positive on CD3.

\section{Heart}

Among the degenerated muscle cells of the myocardium there were diffused proliferates of small and large lypmhocytes. Ther enriched tumor proliferates were in endo and perimysium. The $\mathrm{T}$ - cell immunophenotype was detected at these sites also.

\section{Ovary}

The enriched polymorphous tumor proliferates were situated among the follicles. Because of the large proliferate mass of tumor cells, some follicles were deformed and dilated while the tumor cells revealed CD3 staining.

\section{Nerves}

The histological examination of the schiatic nerve revealed cell infiltrates of small lymphocytes and a discrete number of macrophages. Lymphoproliferation appears in the lesions. There was a small number of lymphoid cells of the T - cell immunophenotype in the nerves collected for the pathohistological examination.

\section{DISCUSSION}

Pathohistological findings in all the examined organs, as well as CD3 positive staining, confirmed the MD diagnosis. Most birds delivered for a pathology section had gross lesions on the visceral organs. Lesions of the peripheral nerves were rare. The dead birds, examined during this work, originated from vaccinated flocks. The tumors were rarely observed during veterinary inspection of such flocks meaning that, the chickens were well protected, and that most likely, very virulent plus strains were not present on the field.

The pathologic changes in the visceral organs were typical for MDV, as described in the available textbooks (Witter and Schat, 2003). The tumors were seen most often in the liver, lungs, spleen, kidneys and heart. The nerves were enlarged in one bird only, and the pathohistologic examination revealed a neoplastic transformation of lymphocytes accompanied by few macrophages. 
Such lesions are well described by Payne et al., 1976 and are according to the proposed designation of type A.

The neoplastic lesions in the visceral organs were typical for MDV. Small, medium size lymphocytes with few inflammatory cells appeared in the tumors. The seen lymphomatous lesions were pleomorphic, which is important in differentiating the diagnosis of Lymphoid leucosis (LL) or reticuloendotheliosis (REV). Opposite to MDV in LL the tumor cell infiltrate consisted of large lypmhoid cells of phenotype $B$. The cells situated in proliferative lesion in LL were of similar size, containing a large cytoplasm. In reticuloendotheliosis (REV), T and B cells were seen in tumor lesions and virology diagnostics was usually undertaken to confirm or exclude REV infection.

In this work additional proof to MDV diagnosis was the excessive finding of CD3 positive cells in tumor proliferates. Evidence that the T - cell population is malignantly transformed after an MDV infection, came from two independent research groups. At Cornell University, Calnek et al., $(1978,1989)$ had established lymphoid cell lines and had proved that transformed cells belong to the $T$ - cell phenotype. Nazerian et al., 1977) also established a T-lymphoblastoid cell line from a JMV tumor transplant. Furthermore, the antibody staining procedure points to T cell markers at the surface of the cell (Powell et al., 1974; Nazerian et al., 1975; Calnek et al., 1989). T-cells involvement in MD tumors was indirectly provided in the experiments of Sharma et al. (1977) who induced the T- cell depletion in chickens and found that those birds experienced smaller tumors after infection with MDV comparing to intact chicken. Schat et al. (1991) found that activated Tcells were transformed by MDV. According to these authors most of the transformed cells were CD4+CD8- phenotypes even though the other phenotype CD4-CD8- and CD4-CD8+ and inflammatory cells were present in the lesions. Having all these results in mind, the CD3 cell population was dominant in MDV lesions while CD4+CD8- and CD4-CD8- lineage was malignantly transformed.

Surprisingly, there was a number of CD79 positive cells in the liver tumors located perivasculary. CD79 antibodies are used as B cell markers in diagnosing human lymphoma (Chu and Arber, 2001). B cells are infected with MDV during the cytolytic phase of infection. Therefore, B cells do play an important role in MDV pathogenesis and their presence in MDV lymphomas was previously reported (Payne et al., 1976). In fact, when fluorescein or radioactive isotope-labeled antibodies for $\mathrm{T}$ and $\mathrm{B}$ cells were used for staining tumor cells it appeared that $75,6 \%$ of $T$ cells and about $17 \%$ of B cells were present in the lesions (Payne, 1876).

B cells are not malignantly transformed and their distribution at the late stage of the MDV infection has not been studied extensively. However, Baignent and Davison (1999) have shown large diffused patches of B cells in the spleen in a susceptible line of chickens (White Leghorn line 7), 4 days post infection. At that time most of the pp38+ (pp38 MDV antigen) cells were found in the B cell lineage. This result points to the role of $B$ cells in cytolytic infection in MDV. MDV (pp38) positive $B$ cells are surrounded by CD $4+$ TCR $\alpha \beta+$ cells, CD $8+T C R \alpha \beta+$ cells implicating the role of cell immune response in the early stage of the MDV infection. It is, therefore, possible that during malignancy, B cells found in the 
lymphoproliferative lesions, are part of the immunologic response in infected chickens. Another possibility that cannot be ruled out is that many CD3 positive cells coexpress CD79 marker, a phenomena found in some lymphoblastic leukemia/lymphoma in humans by Pilozzi et al. (1998). Up to this point we are not in the position to claim that CD79 positive cells are actually T cell lineage, therefore further research will be undertaken to examine the nature of this surface marker in the tumors.

\section{ACKNOWLEDGMENT}

The paper was partially supported by Ministry of Science and Environment Protection Projects numbers Ol 1659 and TR6860B

Address for correspondence:

Dr Milijana Knežević, professor

Faculty of Veterinary Medicine

Bulevar oslobođenja 18, Belgrade

Republic of Serbia

E-mail: mara@vet.bg.ac.yu

\section{REFERENCES}

1. Aleksić-Kovačević S, Gagić M, Lazić S, Kovačević M, 1999, Immunohistochemical detection of infectious bursal disease virus antigen in the bursa of Fabricius of experimentally infected chickens, Acta Vet, 49,13-20.

2. Aleksić-Kovačević S, Knežević M, Jovanović M, Gagić M, 1999, Distribucija virusa zarazne bolesti burze (IBDV) i CD3 T limofcita u fabricijevim burzama eksperimentalno inficiranih pilića, Veterinarki glasnik, 53, 54-6, 221-7.

3. Baigent JS, Smith LP, Venugopal KN, Currie RJW, 2006, Vaccinal control of Marek's disease: Current challenges, and future strategies to maximize protection, Vet Immunol Immunopath, 112, 78-86.

4. Baigent J Susan, Davison TF, 1999, Development and composition of lymphoid lesions in the spleens of Marek's disease virus-infected chickens: association with virus spread and the pathogenesis of Marek's disease, Avian Pathol, 28, 287-300.

5. Calnek BW, Murthy KK Schat KA, 1978, Establishment of Marek's disease lymphoblastoid cell lines from transplantable versus primary lymphomas, Int $J$ Cancer, 21,100-7.

6. Calnek BW, Lucio B, Schat KA, Lillehoj HS, 1989, Pathogenesis of Marek's disease virus-induced local lesions. 1. Lesion characterization and cell line establishment, Avian Dis, 33, 291-302.

7. Chu P, Arber D, 2001, CD79: A review, Appl Immunohistochem Mol Morph, 9, 97-106.

8. Ficken MD, Nasisse MP, Boggan GD, Guy JS, Wages DP et al, 1991, Marek's disease virus isolates with unusual tropism and virulence for ocular tissues: Clinical findings, challenge studies and pathological features, Avian Pathol, 20, 461-74.

9. Nazerian K, Sharma JM, 1975, Brief communication: detection of T cell surface antigens in Marek's disease lymphhoblastoid cell line, J Natl Cancer Inst, 54, 277-9.

10. Nazerian K, Stephens EA, Sharma JM, Lee LF, Gailitis $M$ et al, 1977, A nonproducer T lymphoblastoid cell line from Marek's disease transplantable tumor (JMV), Avian Dis, 21, 60-76.

11. Payne LN, Frazier JA, Powell PC, 1976, Pathogenesis of Marek's disease, Int Rev Exp Biol, 16, 59154.

12. Pilozzi E, Pulford K, Jones M, Hermelnik Hans-Konrad M, Falini B et al, 1988, Co-expression of CD79a (JCB117) and CD3 by lymphoblastic lymphoma, J Pathol, 186,140-3.

13. Powell PC, Payne LN, Frazier JA, Rennie M, 1974, T lymphoblastoid cell lines from Marek's disease lymphomas, Nature, 251, 79-80.

14. Schat AK, Chen-Lo HC, Calnek WB, Char D, 1991, Transformation of T-lymphocyte subset by Marek's disease herpesvirus, $J$ Virol, 65,1408-13. 
15. Sharma JM, Nazerian K, Witter RL, 1977, Reduced incidence of Marek's disease gross lymphomas in T cell-depleted chickens, J Natl Cancer Inst, 58,689-92.

16. Sharma JM, Zhang Y, Jensen D, Rautenschlein S, Yeh YH, 2002, Field trial in commercial broilers with a multivalent in ovo vaccine comprising a mixture of live viral vaccines against Marek's disease, infectious bursal disease, Newcastle disease, and fowl pox, Avian Dis, 46, 613-22.

17. Witter RL Lee LF, 1984, Polivalent Marek's disease vaccines: safety, efficacy and protective synergism in chickens with maternal antibodies, Avian Pathol, 13, 75-92.

18. Witter RL, 1997, Increased virulence of Marek's disease virus filed isolates, Avian Dis, 41, 149-63. 19. Witter RL, Schat KA, 2003, Marek's disease, In: Saif YM editor in chief, Disease of Poultry $11^{\text {th }}$ Edition, Blackwell Publishing Co, lowa State Press, 407-65.

\title{
MORFOLOŠKO I IMUNOCITOHEMIJSKO ISPITIVANJE TUMORSKIH ĆELIJA KOD MAREKOVE BOLESTI
}

\author{
PEJOVIĆ N, VELHNER MAJA, POLAČEK V, ALEKSIĆ-KOVAČEVIĆ SANJA, \\ MARINKOVIĆ D i KNEŽEVIĆ MILIJANA
}

\section{SADRŽAJ}

U ovom radu su opisane makroskopske, mikroskopske i imunofenotipske karakteristike tumora kod Marekove bolesti (MB). Ispitivanjem su bili obuhvaćeni jetra, bubreg, pluća, srce, žlezdani želudac, jajnik i nervi ishijadičnog pleksusa dvadeset pilića starosti između 8 i 24 nedelje.

$U$ ispitivanom materjalu ustanovljeno je limfoproliferativno bujanje $u$ različitim organima, fokalnog ili difuznog karaktera, pri čemu su zahvaćeni organi znatno povećani, kompaktni i veoma krti, često nepravilnog oblika, sivocrveni ili sivobeli, slaninastog izgleda. Najčešće i najkarakterističnije su bili promenjeni slezina, jetra, žlezdani želudac, jajnici koji obično predstavljaju kompaktne ili izbrazdane tvorevine poput karfiola, slaninastog izgleda i različite veličine. Histološki, u oganima se nalaze proliferati malih i srednjih limfocita, zatim limfoblasta, ćelija Marekove bolesti i aktivisane retikulumske ćelije. Tumorski proliferati su predominantno sastavljeni od limfoblasta i imaju sve karakteristike limfoma. Imunohistohemijskom analizom je ustanovljeno da su ćelije limfoma kod MB predominantno T ćelijskog tipa, CD3 fenotipa. U proliferatu u jetri su nađene i brojne CD79 pozitivne ćelije lokalizovane perivaskularno, što predstavlja interesantan nalaz i zahteva dalja ispitivanja. 